\title{
The study of serum calcium and serum magnesium in pregnancy induced hypertension and normal pregnancy
}

\author{
Jagannath Pairu*, Triveni GS, Ankitha Manohar
}

\begin{abstract}
Department of Obstetrics \& Gynaecology, Vanivilas Hospital, Bangalore Medical College and Research Institute, Fort, Bangalore-560002, Karnataka, India
\end{abstract}

Received: 02 November 2014

Accepted: 10 December 2014

\section{*Correspondence: \\ Dr. Jagannath Pairu, \\ E-mail: pairujgannath@yahoo.com}

Copyright: (C) the author(s), publisher and licensee Medip Academy. This is an open-access article distributed under the terms of the Creative Commons Attribution Non-Commercial License, which permits unrestricted non-commercial use, distribution, and reproduction in any medium, provided the original work is properly cited.

\begin{abstract}
Background: Preeclampsia along with its complications is one of the major causes of maternal and fetal mortality and morbidity. Association of calcium and magnesium with pregnancy induced hypertension is known since decades. Evidence of decreased serum calcium and decreased serum magnesium has been observed in patients with pregnancy induced hypertension and has been implicated in the etiopathogenesis of preeclampsia.

Methods: The present study was undertaken in 100 pregnant women. Data for the study was collected from 50 normotensive pregnant women with more than 20 weeks of gestational age (control group) and 50 pregnancy induced hypertension patients (study group) attending for the antenatal care in department of obstetrics and gynaecology in Vanivilas hospital, Bowring and Lady Curzon hospital attached to Bangalore medical college and research institute. Cases and controls were matched. Serum calcium and serum magnesium levels were estimated by spectrophotometry method.

Results: The mean serum calcium is significantly lower in pregnancy induced hypertension group $(8.15 \pm 0.37 \mathrm{mg} / \mathrm{dl})$ compared to normal pregnancy $(9.16 \pm 0.82 \mathrm{mg} / \mathrm{dl})$. The mean serum magnesium is lower in pregnancy induced hypertension group $(1.78 \pm 0.70 \mathrm{mEq} / \mathrm{L})$ than normal pregnancy $(2.08 \pm 0.46 \mathrm{mEq} / \mathrm{L})$ which is moderately significant. Conclusions: The serum calcium and serum magnesium levels are decreased in pregnancy induced hypertension patients compared to normotensive normal pregnant women, suggesting the possible role of calcium and magnesium in etiopathophysiology of pregnancy induced hypertension.
\end{abstract}

Keywords: Serum calcium, Serum magnesium, Pregnancy induced hypertension, Normal pregnancy

\section{INTRODUCTION}

Hypertension in pregnancy is second most common cause for maternal mortality. It is estimated that up to $30 \%$ of perinatal deaths are related to hypertensive disorders of pregnancy. ${ }^{1}$ Incidence of pregnancy induced hypertension is around 5 to $8 \%$ of all pregnant women. ${ }^{2}$

The etiology of pregnancy induced hypertension is unknown. Why pregnancy incites or aggravates hypertensive vascular disease remains unsolved despite decades of intensive research worldwide. And there is confusion about its classification, diagnosis, and treatment. More than 100 names have been given to this disease. ${ }^{3}$

The term pregnancy induced hypertension is quite commonly used and encompasses hypertension, either with proteinuria (Preeclampsia) or without proteinuria (gestational hypertension). ${ }^{4}$ In this study the word preeclampsia is used synonymously with pregnancy induced hypertension.

A number of dietary deficiencies or excesses have been blamed as the cause for preeclampsia over centuries. 
Studies have shown relationship between dietary deficiencies and incidence of preeclampsia. Some studies conclude malnutrition as risk factor in the etiology of preeclampsia because of its higher incidence in developing countries. And implicate it by deficit in the intake of calcium, magnesium, zinc. ${ }^{5-7}$

Association of serum calcium and magnesium with pregnancy induced hypertension is known since decades. Manipulations of sodium, magnesium, calcium, zinc intake have received interest. Epidemiologic data show an inverse relationship between calcium intake and pregnancy induced hypertension. Calcium supplementation can lower blood pressure and reduce the incidence of preeclampsia in pregnant women. ${ }^{5-7}$

Pregnancy is a period of high calcium demand because of fetal requirement. Pregnancy entails number of physiological events with implications regarding calcium metabolism: the extracellular fluid expands, the albumin level decreases, the glomerular filtration rate increases causing increase in calciuria and calcium is removed from the maternal system by transfer to fetus. These mechanisms all tend to promote lowering of maternal calcium concentration and present pregnant women for maintaining the levels within the narrow range necessary to preserve homeostasis. ${ }^{8,9}$

On the physiological basis, calcium plays an important role in muscle contraction and regulation of water balance in cells. Modification of plasma calcium concentration leads to alteration of blood pressure. The lowering of serum calcium and the increase of intracellular calcium can cause an elevation of blood pressure in preeclamptic mothers. ${ }^{10}$

Generally hypomagnesaemia in most of pregnant women is associated with haemodilution, renal clearance, consumption of minerals by the growing fetus. There is decrease in ionized and total magnesium levels with increasing gestational age during normal pregnancy, as well as evidence of magnesium disturbance in women who later developed pre eclampsia. Magnesium levels may have significant effects on cardiac excitability and on vascular tone, contractility and reactivity. Magnesium causes vascular muscle relaxation. ${ }^{11,12}$

Pregnancy induced hypertension is characterised by vasospasm, elevated blood pressure and increased neuromuscular irritability, features common to syndromes of magnesium deficiency. ${ }^{13}$

\section{METHODS}

\section{Source of data}

The present study was undertaken in 100 pregnant women. Data for the study was collected from 50 normotensive normal pregnant women with more than 20 weeks of gestational age (control group) and 50 pregnancy induced hypertension patients (study group) attending for the antenatal care in Department of Obstetrics and Gynecology in Vanivilas hospital, Bowring and Lady Curzon hospital attached to Bangalore medical college and research institute.

Cases were selected randomly. Serum calcium and Serum magnesium levels were estimated by spectrophotometry method. Cases and controls were matched as far as possible.

\section{Study design}

A comparative study to evaluate the levels of serum calcium and serum magnesium in pregnancy induced hypertension and normal pregnancy. To correlate the serum levels of calcium and magnesium with the pregnancy induced hypertension.

\section{Inclusion criteria}

Study group:

1. Diagnosed pregnancy induced hypertension based on criteria - blood pressure $\geq 140 / 90 \mathrm{mmHg}$ on two separate occasions 6 hours apart, Proteinuria more than $300 \mathrm{mg}$ in 24 hour urine or 1+ dipstick in two midstream urine samples collected 4 hours apart, with or without edema, in more than 20 weeks gestational age.

2. Singleton pregnancy

3. Age $15-40$ years

4. Non diabetic

Control group:

1. More than 20 weeks gestational age

2. Singleton pregnancy

3. Age $15-40$ years

4. Non diabetic

\section{Exclusive criteria}

1. Chronic hypertension

2. Gestational diabetes mellitus

3. Renal disease

The subjects included in this group were out patients and inpatients of above mentioned hospitals.

Patients were selected for the study based on the inclusion criteria and by subjecting them to history taking, clinical examination - general physical examination, vitals, systemic examination.

The study protocol was approved by the ethical committee of the Bangalore medical college and research institute and written informed consent was obtained from each woman before inclusion in the trial. 


\section{Collection of blood samples}

About $5 \mathrm{ml}$ of venous blood was collected in a clean and dry centrifuge tubes. Blood was allowed to clot; serum was separated from the clot by centrifugation. Serum calcium and magnesium was measured by spectrophotometry.

\section{Serum calcium estimation}

Normal range of serum calcium is $8.4-10.4 \mathrm{mg} / \mathrm{dl}$, or 4.25-5.2 mEq/L

Methodology: Arsenazo III method, end point

Principle: Arsenazo III combines with calcium ions at $\mathrm{pH}$ 6.75 to form a coloured chromophore, the absorbance of which is measured at $650 \mathrm{~nm}(630-660 \mathrm{~nm})$ and is proportional to calcium concentration. Arsenazo III has a high affinity for calcium ions and shows no interference from other cations normally present in serum, plasma, urine.

Calculations for serum calcium $(\mathrm{mg} / \mathrm{dl})=($ Absorbance of test/Absorbance of standard) $\times$ Concentration of standard $(\mathrm{mg} / \mathrm{dl})$

SI conversion factor: $1 \mathrm{mg} / \mathrm{dl}=1 \mathrm{mmol} / \mathrm{L} \times 4$

\section{Serum magnesium estimation}

Normal Range of Serum magnesium is $1.3-2.5 \mathrm{mEq} / \mathrm{L}$

Methodology: Calmagite method

Principle: Magnesium combines with Calmagite in an alkaline medium to form a red coloured complex. Interference of calcium and proteins is eliminated by the addition of specific chelating agents and detergents. Intensity of the colour formed is directly proportional to the amount of magnesium present in the sample.

Procedure: Wavelength/filter: 510 nm (Hg 546 nm)/green

Temperature: Room temperature

Light path: $1 \mathrm{~cm}$

Calculations: Magnesium in $\mathrm{mEq} / \mathrm{L}=($ Abs.T/Abs. $\mathrm{S}) \times 2$

SI conversion factor: $2 \mathrm{mEq} / \mathrm{L}=1 \mathrm{mmol} / \mathrm{L}=2.44 \mathrm{mg} / \mathrm{dl}$

\section{Method of statistical analysis}

Descriptive statistical analysis has been carried out in the present study. Results on continuous measurements are presented on Mean \pm SD (Min-Max) and results on categorical measurements are presented in number $(\%)$.
Significance is assessed at 5\% level of significance, student $t$ test ( two tailed, independent) has been used to find the significance of study parameters on continuous scale between two groups Chi-square/Fisher exact test has been used to find the significance of study parameters on categorical scale between two or more groups. Student $t$ test has been used to find the homogeneity of parameters on continuous scale and Chi-square/Fisher exact test has been used to find the homogeneity of samples on categorical scale.

\section{RESULTS}

A comparative clinical study (case-control study) with 50 patients (PIH) and 50 normal pregnant women is undertaken to study the serum calcium and serum magnesium the present study was well matched in age between both groups and comparable with the mean age in study group $22.80 \pm 2.28$ years, control group $23.80 \pm$ 4.25. Majority of patients are in 21-25 year group in both study (46\%) and controls (54\%) (Table 1).

Table 1: Comparison of age distribution in case and control group.

\begin{tabular}{|lllll|}
\multirow{2}{*}{ Age (years) } & \multicolumn{2}{l}{ Controls } & \multicolumn{2}{l|}{ Cases } \\
& No. & $\mathbf{\%}$ & No. & $\mathbf{\%}$ \\
\hline $18-20$ & 18 & 36.0 & 15 & 30.0 \\
\hline $21-25$ & 27 & 54.0 & 23 & 46.0 \\
\hline $26-30$ & 4 & 8.0 & 8 & 16.0 \\
\hline $31-35$ & 1 & 2.0 & 4 & 8.0 \\
\hline Total & 50 & 100.0 & 50 & 100.0 \\
\hline Mean \pm SD & $22.80 \pm 2.88$ & $23.80 \pm 4.25$ \\
\hline
\end{tabular}

Mean systolic blood pressure in study group was 150.34 $\pm 9.98 \mathrm{mmHg}$ and in controls $114.88 \pm 8.24 \mathrm{mmHg}$.

Mean diastolic blood pressure in study group was 100.40 $\pm 9.29 \mathrm{mmHg}$ and in controls $74.64 \pm 6.17 \mathrm{mmHg}$ (Table 2).

Table 2: Comparison of mean BP in control and case group.

\begin{tabular}{|llll|}
\hline BP $(\mathrm{mm} \mathrm{Hg})$ & Controls & Cases & P value \\
\hline SBP $(\mathrm{mm} \mathrm{Hg})$ & $114.88 \pm 8.24$ & $150.34 \pm 9.98$ & $<0.001^{* *}$ \\
\hline DBP $(\mathrm{mm} \mathrm{Hg})$ & $74.64 \pm 6.17$ & $100.40 \pm 9.29$ & $<0.001^{* *}$ \\
\hline
\end{tabular}

The Table 3 shows the concentration of serum calcium in controls as $9.16 \pm 0.82$ and in study group $8.15 \pm 0.37$ $\mathrm{mg} / \mathrm{dl}$ with $\mathrm{P}$ value $<0.001$.

The serum magnesium levels in controls $2.08 \pm 0.46$ and in study group as $1.78 \pm 4.70 \mathrm{mEq} / \mathrm{L}$ with $\mathrm{P}$ value 0.013 .

The serum calcium and magnesium has significantly decreased in cases compared to controls. 
Table 3: Comparison of serum calcium and serum magnesium in two groups.

\begin{tabular}{|lll|l|}
\hline $\begin{array}{l}\text { Outcome } \\
\text { variables }\end{array}$ & Controls & Cases & P value \\
\hline $\begin{array}{l}\text { Serum calcium } \\
(\mathrm{mg} / \mathrm{dl})\end{array}$ & $\begin{array}{l}9.16 \pm 0.82 \\
(7.80-12.00)\end{array}$ & $\begin{array}{l}(7.15 \pm 0.37 \\
(7.9 .00)\end{array}$ & $<0.001^{* *}$ \\
\hline $\begin{array}{l}\text { Serum } \mathrm{Mg} \\
(\mathrm{mEq} / \mathrm{L})\end{array}$ & $2.08 \pm 0.46$ & $1.78 \pm 0.70$ & $0.013^{*}$ \\
\hline
\end{tabular}

\section{DISCUSSION}

The present study was carried out to compare the serum calcium and magnesium levels in $50 \mathrm{PIH}$ cases with 50 normal pregnancies (as controls) and to correlate the values with the pregnancy induced hypertension. Both cases and controls clinically examined, inclusion and exclusion criteria fulfilled.

The mean serum concentration of calcium in normal pregnancy is $9.16 \pm 0.82 \mathrm{mg} / \mathrm{dl}$ and in pregnancy induced hypertension is $8.15 \pm 0.37 \mathrm{mg} / \mathrm{dl}$. The mean serum calcium concentration in pregnancy induced hypertension patients is decreased as compared to normal pregnancy and this decrease is of high statistical significance with $\mathrm{p}$ value $<0.001$. This study result was similar to the result of various other studies like Nasser O Malas et al., ${ }^{14}$ Kanchanpan Sukonpan et al. ${ }^{15}$ Chanvitya Punthumapol MD et al., ${ }^{16}$ Idogun ES et al., ${ }^{17}$ Jain $S$ et al. ${ }^{18}$

The present study result was contradictory to some studies that the mean serum calcium levels in preeclampsia were not different from normal pregnancy like A Amirabi et al., ${ }^{19}$ Villanueva $S$ et al., ${ }^{20}$ Magri et al. ${ }^{21}$

A tendency to relative maternal hypocalcaemia during pregnancy has been recognised for more than 40 years. Total calcium tends to decrease over the course of pregnancy in normal women and decreased significantly during pregnancy in women who developed preeclampsia. The decrease in serum calcium levels principally involves the protein bound portion and haemodilution.

Belzian and associates 1983 noted decreased calcium levels in preeclampsia and achieved decrease in blood pressure with calcium supplementation. ${ }^{22,23}$

In this study serum concentration of magnesium in normal pregnancy and pregnancy induced hypertension is $2.08 \pm 0.46 \mathrm{mEq} / \mathrm{L}$ and $1.78 \pm 0.70 \mathrm{mEq} / \mathrm{L}$ respectively. The mean serum magnesium concentration is decreased in preeclampsia compared to normal pregnancy. The $\mathrm{P}$ value is 0.013 which is of moderate significance.

The present study results are comparable to study reports of K. Srivastava et al., ${ }^{24}$ Kisters et al. $1990,{ }^{25}$ Pralhad et al., ${ }^{26}$ Jain $\mathrm{S}$ et al. ${ }^{18}$ The present study did not support the study results of Idogun ES et al., ${ }^{27}$ A. Amirabi et al., ${ }^{19}$ Chanvitya Punthumapol et al. ${ }^{16}$
Cynthia A. Standly et al. 1994 reported hypomagnesemia is a constant feature in pregnancy. An increase in renal clearance during pregnancy, poor dietary intake, consumption of minerals by growing fetal skeletal system, hemodilution, all contribute to hypomagnesemia.

In this study hypomagnesaemia has not been encountered in controls but a significant number of preeclampsia patients showed a tendency towards hypomagnesaemia. The cause effect pattern is to be analysed.

Some studies like Sanders GT et al. 1999, Francois Beguin et al. have shown that serum magnesium was even higher in pre-eclamptic group than in normal pregnancy. The difference may be explained by the variation of the studied population and the dietary intake.

The study data supported the hypothesis that calcium and magnesium deficiency might be the cause in the development of preeclampsia. The consequence of the deficiencies of the calcium and magnesium may be responsible for the clinical manifestations that are observed in preeclampsia and eclampsia patients since both ions are important in cellular and neuronal metabolism as well as cell membrane stability. ${ }^{27}$

\section{Funding: No funding sources \\ Conflict of interest: None declared}

Ethical approval: The study was approved by the ethics committee of Bangalore medical college and research institute

\section{REFERENCES}

1. WHO. The hypertensive disorders of pregnancy. WHO Tech Rep Ser. 1987;758:93-4.

2. James DK, Steer PJ, Weiner CP, Gonik B. Pregnancy induced hypertension. In: James DK, Steer PJ, Weiner CP, Gonik B, eds. High Risk Pregnancy Management Options. 3rd ed. Philadelphia: WB Saunders; 2001: 772-778.

3. Davey DA, MacGillivray I. The classification and definition of Hypertensive disorders of pregnancy. Clin Exp Hypertens(B). 1986;51:97-133.

4. Helena Salonen Ros. Preeclampsia and other circulatory diseases during pregnancy - etiological aspects and impact on female offspring. Karolinska: University Press Stockholm; 2001: 1-61.

5. Belijan JM, Villar J. The relationship between calcium intake and edema-proteinuria, and hypertension-gestosis: a hypothesis. Am J Clin Nutr. 1980;33:2202-10.

6. Carroli G, Duley L, Belijan JM, Villar J. Calcium supplementation during pregnancy: a systematic review of randomised controlled trials. $\mathrm{Br} \mathrm{J}$ Obstet Gynaecol. 1994;101:753-8.

7. Caughey AB, Stotland NE, Washington AE, Escobar GJ. Maternal ethnicity, Paternal ethnicity and paternal ethnic discordance; predictors of preeclampsia. Obstet Gynaecol. 2005;106:156-61. 
8. Potkin RM, Reynolds WA, Williams GA, Hargis GK. Calcium metabolism in normal pregnancy: a longitudinal study. Am J Obstet Gynaecol. 1979;133:781-90.

9. Cunningham FG, Leveno KJ, Bloom SL, Hauth JC, Gilstrap L, Wenstrom KD. Williams Obstetrics. In: Cunningham FG, Leveno KJ, Bloom SL, Hauth JC, Gilstrap L, Wenstrom KD, eds. A Book. 22 ed. New York: McGraw Hill; 2005: 129,142-143, 762-780.

10. Ray J, Vasishta K, Kaur S, Majumdar S, Sawhney H. Calcium metabolism in preeclampsia. Int J Gynaecol Obstet. 1999;66:245-50.

11. Tong GM, Rude RK. Magnesium deficiency in critical illness. J Intensive Care Med. 2005;20:3-17.

12. Touy ZRM. Role of magnesium deficiency in pathogenesis of hypertension. Mol Aspects Med. 2003;24:107-36.

13. Gerard T. Sanders, Heink J. Huijgen. Magnesium in disease. ASOR J. 1999;37(11-12):1011-33.

14. Naser O. Malas. Does serum calcium in preeclampsia and normal pregnancy differ? Saudi Med J. 2001;22(10):868-71.

15. Kanchanpan Sukonpan, Vorapong Phupong. Serum calcium and serum magnesium in normal and preeclamptic pregnancy. Arch Gynaecol Obstet. 2005;273(1):12-6.

16. Chanvitya Punthumapol, Boonsri Kittichotpanich. Serum calcium, magnesium and uric acid in preeclampsia and normal pregnancy. J Med Assoc Thai. 2008;91(7):968-73.

17. Idogun ES, Imarengiaye $\mathrm{CO}$, Momoh SM. Extracellular calcium and magnesium in preeclampsia and eclampsia. Afr J Reprod Health. 2007 Aug;11(2):80-5.

18. Jain S, Priyamvada Sharma, Shobha K, Govind Mohan, Saroj Singh. The role of calcium and magnesium and zinc in preeclampsia. Biol Trace Elem Res. 2010 Feb;133(2):162-70.

19. Amirabi A, Golmohammad lou S, Yazdian M, Pashapour N. Evaluation of serum calcium, magnesium, copper, zinc levels in women with preeclampsia. Iran J Med Sci. 2008;33(4):231-4.

20. Villanueva LA, Figueroa A, Villanueva S. Blood concentration of calcium and magnesium in women with severe preeclampsia. Gynaecol Obstet Mex. 2001 Jul;67:277-81.

21. Magri J, Sammut M, Savon C. Lead and other metals in gestational hypertension. Int $\mathrm{J}$ Gynaecol Obstet. 2003;83:29-36.

22. Belijan JM, Villar J, Repke J. The relationship between calcium intake and pregnancy induced hypertension, upto date evidence. Am J Obstet Gynaecol. 1988;158:898-902.

23. Belijan JM, Villar J, Zalazer A, Rojas L, Chan D, Bryce GF. Preliminary evidence of effect of calcium supplementation on blood pressure in normal pregnant women. Am J Obstet Gynaecol. 1983a;146:175-80.

24. Srivastava K, Jina R, Kar J, Mishra RK, Singh VB, Sharma N. Serum magnesium in normal pregnancy and abnormal pregnancy. J Obstet Gynaecol India. 2001;51(4):38-40.

25. Kisters K, Niedner W, Zidek WA. Maternal plasma concentrations of magnesium, calcium, zinc, and copper in normal and pathological pregnancies. Sci Total Environ. 1990 Dec;99(1-2):67.

26. Prahlad Kushtagi, Kuntal Rao. Serum minerals calcium, magnesium, copper, zinc in pregnancy induced hypertension. Indian J Obstet Gynaecol. 1993 Feb;43:33-6.

27. Idogun ES, Imarengiaye CO, Momoh SM. Extracellular calcium and magnesium in preeclampsia and eclampsia. Afr J Reprod Health. 2007 Aug;11(2):80-5.

DOI: $10.5455 / 2320-1770$. ijrcog20150205

Cite this article as: Pairu J, Triveni GS, Manohar A. The study of serum calcium and serum magnesium in pregnancy induced hypertension and normal pregnancy. Int J Reprod Contracept Obstet Gynecol 2015;4:30-4S. 